\title{
OSOBINE LIČNOSTI I STRATEGIJE PREVLADAVANJA STRESA KAO PREDIKTORI SINDROMA SAGOREVANJA KOD SPORTISTA
}

\begin{abstract}
Apstrakt
U radu su predstavljeni rezultati istraživanja čiji je osnovni cilj bio da se ispitaju relacije između osobina ličnosti, strategija prevladavanja stresa i sindroma sagorevanja, kao i da se utvrdi da li su osobine ličnosti i strategije prevladavanja stresa statistički značajni prediktori sindroma sagorevanja kod sportista. U istraživanju je učestvovalo 153 ispitanika oba pola (92 muškarca, 61 žena), sportista koji se bave ekipnim sportovima (odbojka, fudbal, rukomet, košarka i vaterpolo). Od instrumenata je korišćen HEXACO-PI-R upitnik za merenje šest dimenzija ličnosti (Lee \& Ashton, 2004; Ashton \& Lee, 2006). Za ispitivanje strategija prevladavanja stresa korišćena je adaptacija CISS skale Endlera i Parkera (1990) koju potpisuju Sorić i Proroković (2002). Burnout sindrom u sportu meren je uz pomoć ABQ skale (Raedeke \& Smith, 2001). Rezultati su pokazali da je od osobina ličnosti Ekstraverzija statistički značajan prediktor subskala Smanjenog osećaja uspeha, Sportske devalvacije, ali i Generalnog sindroma sagorevanja. Savesnost se pokazala kao značajan prediktor za Emocionalnu i fizičku iscrpljenost. Izbegavanje, jedna od strategija prevladavanja stresa, se pokazala kao statistički značajan prediktor za Emocionalnu i fizičku iscrpljenost i Generalni doživljaj sindroma sagorevanja. Visok skor na svim navedenim skalama ukazuje na manju mogućnost doživljaja sindroma sagorevanja. Predikcija sindroma sagorevanja kod sportista na osnovu osobina ličnosti i strategija prevladavanja stresa, pa samim tim i uvid u varijable koje su važne za doživljaj ovog sindroma, svakako može imati značajne praktične implikacije u razjašnjavanju faktora koji doprinose stvaranju doživljaja sindroma sagorevanja, koji je jedan od glavnih psiholoških razloga povlačenja iz profesionalnog sporta.
\end{abstract}

Ključne reči: osobine ličnosti, strategije prevladavanja stresa, sindrom sagorevanja, sportisti

\section{Uvod}

Pojam ličnosti je tako širok da ga je teško precizno definisati. Bez obzira na to što se definicija stavlja na prvo mesto, uvek će biti onih koji će reći da je preširoka ili preuska. Jedna definicija koja je izdržala test vremena je ona koju je predložio Olport (Allport, 1937), koji je rekao da je ličnost ,dinamična organizacija onih psihičkih sistema unutar pojedinca koji određuju njegovo jedinstveno prilagođavanje okolini“" (str. 48).

\footnotetext{
${ }^{1}$ Adresa autora: nkaraleić94@gmail.com
} 
U poslednje dve decenije dvadesetog veka, model Velikih Pet se razvio u dominantnu teorijsku i istraživačku paradigmu kada je u pitanju struktura bazičnih crta ličnosti (Costa \& McCrae, 2008; Goldberg, 1990; John, Naumann, \& Sotto, 2008). Po ovom modelu ličnost je struktuirana iz pet bazičnih, međusobno ortogonalnih crta: Neuroticizam, Ekstraverzija, Otvorenost, Saradljivost i Savesnost. Ovih pet crta su se pokazale kao uspešni prediktori različitih vrsta ponašanja (Paunonen \& Ashton, 2001). Međutim, studije izvršene krajem devedesetih godina dale su naznake da treba ispitati šestofaktorsku strukturu latentnih dimenzija koje stoje iza deskriptoraličnosti u različitim jezicima. Verovatno najpoznatiju operacionalizaciju ovako revidiranog leksičkog modela ličnosti predstavlja HEXACO struktura (Lee \& Ashton, 2008), čiji je naziv akronim za dimenzije koje su u njemu reprezentovane: Poštenje (H-Honesty/Humility), Emocionalnost (E-Emotionality), Ekstraverzija (X-eXtraversion), Saradljivost (A-Agreeableness), Savesnost (C-Conscientiousness) i Otvorenost (O-Openness).

U domenu sporta, ispitivanje ličnosti može biti od velikog značaja. Od 1960. godine, nekoliko istraživanja je urađeno na ovu temu koja su pokušala da razjasne odnos između ličnosti i sportskog postignuća (Cofer \& Johnson, 1960; Cooper, 1969; Hardman, 1973; Morgan, 1980; Oglivie, 1968, 1976, prema Cox, 2005). Od svih navedenih, Morganov pregled je pružio najobuhvatniju obradu ovog problema. Iako nije u potpunosti zagovarao lakoverno stanovište, Morgan je naveo da literatura pokazuje dosledan odnos između ličnosti i sportskog postignuća kada su: a) uklonjene različitosti i b) podaci analizirani korišćenjem multivarijantnog pristupa.

Sportisti se razlikuju od „nesportista“ u mnogim osobinama ličnosti (Geron, Furst \& Rotstein, 1986). Uvek se raspravlja o tome ko je tu u prednosti. Šur, Ešeli i Džoj (Schurr, Ashely, \& Joy, 1977) jasno su pokazali da su sportisti koji učestvuju u timskim i individualnim sportovima nezavisniji, objektivniji i manje anksiozni od onih koji se ne bave sportom. Iz pregleda Hardmena (Hardman, 1973), takođe je jasno da su sportisti često inteligentniji od proseka. Zatim, Kuper (Cooper, 1969) opisuje sportiste kao samouverenije, sposobnije i socijalno otvorenije od nesportista. To potvrđuju i zaključci Morgana (Morgan, 1980) i Kanea (Kane, 1976) da su sportisti u osnovi ekstravertni i niske anksioznosti. Neka istraživanja potvrđuju ove podatke, na primer: vrhunski alpinisti u poređenju sa kontrolnom grupom manifestuju nisku anksioznost, emocionalnu suzdržanost, nizak superego, ali visok skor potrebe za traženjem uzbuđenja (Magni, Rupolo, Simini, DeLeo, \& Rampazzo, 1985; Robinson, 1985, prema Cox, 2005).

Termin stres veoma je rasprostranjen pojam u svim oblastima ljudskog delovanja. Predmet je interesovanja i istraživanja različitih naučnih disciplina od bioloških, medicinskih, psiholoških do socioloških, i u svakoj oblasti se razlikuje ono što se ovim terminom označava. Danas bi svako mogao reći nešto o stresu, bez obzira da li se radi o laiku ili naučniku. Zato je veoma teško dati univerzalnu definiciju stresa.

Najprihvaćenija definicija (Zotović, 2007) jeste da je stres svaka promena u spoljašnjoj sredini ili u našem telu, koja utiče na nas pozitivno ili negativno.

Stres koji nije adekvatno regulisan u sportu može se dovesti u usku povezanost sa povećanom anksioznošću i pojavom sindroma sagorevanja, povećanom 
agresivnošću i nasilničkim ponašanjem, smanjenjem samopoštovanja i uživanja u sportu i problemima prilikom izvođenja motoričkih zadataka (Burton \& Raedeke, 2008). „Stres nas ne ubija, već vešto suočavanje sa njim nam dozvoljava da živimo“ (Vailant prema Vlajković, 2005, str. 47). Iz stresne situacije možemo izaći snažniji i jači ukoliko nađemo adekvatan način da se sa njom suočimo. Koncept prevladavanja odnosi se na različite oblike ponašanja koji za cilj imaju da smanje dejstvo stresnih situacija. Prevladavanje (coping) po pravilu znači akcija, bilo na nivou ponašanja ili na kognitivnom nivou.

Smatra se (Zotović, 2007) da uspešno prevladavanje stresa treba da postigne nekoliko ciljeva: 1) smanji pretnju koja dolazi iz spoljašnje sredine i poveća šanse za oporavak od stresa; 2) omogući tolerisanje ili prilagođavanje osobe na negativne događaje u realnosti; 3) omogući održavanje pozitivne slike o sebi; 4) održi emocionalnu stabilnost i 5) omogući održavanje adekvatnih relacija osobe sa drugim ljudima.

Stilovi suočavanja su (Endler \& Parker, 1990):

- Suočavanje usmereno na zadatak (problem) - obuhvata akcije koje predstavljaju pokušaj da se reši i preformuliše stresna situacija ili minimiziraju njeni efekti.

- Suočavanje usmereno na emocije - obuhvata strategije za odvlačenje pažnje, fantaziju ili druge svesne aktivnosti čiji je cilj regulacija efekta.

- Izbegavanje - obuhvata odvraćanje pažnje od bilo kakvih znakova vezanih za stresni događaj. Deli se na: distrakciju i socijalnu diverziju. Distrakcija uključuje tvrdnje koje opisuju suočavanje sa aktivnostima koje uglavnom iziskuju trošenje novca (npr. „Častim se omiljenim jelom i pićem”, „Kupim nešto za sebe"). Socijalna diverzija se odnosi na razonodu, razgaljivanje i zaboravljanje neprijatnih misli i briga kroz učestale socijalne kontakte i socijalnu podršku. Ovu strategiju (Izbegavanje) generalno karakteriše udaljavanje od izvora stresa i obuhvata kognitivne, emocionalne i ponašajne pokušaje udaljavanja od stresne situacije. Nepreduzimanje akcije, negiranje da se događaj desio, potiskivanje emocija, zloupotreba alkohola, maštanje, sanjarenje neke su od izbegavajućih strategija (Endler \& Parker, 1990).

Strategije prevladavanja stresnih situacija razlikuju se s obzirom na uzrast, pol i uspešnost sportista. Stariji adolescenti primenjuju veći broj i repertoar strategija prevladavanja stresa od mlađih adolescenata, koristeći strategije koje su više usmerene na zadatak i emocije, a manje strategije koje podrazumevaju izbegavanje (Reeves, Nicholls, \& McKenna, 2009). U pogledu razlike između uspešnih i manje uspešnih sportista u vezi sa strategijama prevladavanja stresa utvrđeno je da uspešniji sportisti oba pola, manje koriste izbegavajuće strategije prevladavanja u odnosu na manje uspešne saigrače i saigračice (Anshel \& Kaissidis, 1997).

Koncept sindroma sagorevanja je prvenstveno bio predstavljen od strane Frojdenbergera (Freudenberger, 1974). On ga je definisao kao specifično psihološko stanje u kojem ljudi pate od emocionalne iscrpljenosti, od osećanja nedostatka ličnog 
uspeha $\mathrm{i}$ imaju tendenciju demoralizacije drugih. On sugerira da sagorevanje vodi ka pogoršanju kvaliteta nege ili usluge koju pruža osoblje.

Černis (Cherniss, 1980) je identifikovao da, u procesu sagorevanja, i stav i ponašanje se menjaju i predstavljaju nekonstruktivni odgovor na stres doživljen na poslu. Sportisti neprestano stvaraju osetljivu ravnotežu između treniranja i prekomernog treniranja, budući da uspeh u sportu zavisi od treniranja.

Ukupan učinak dodatnog treniranja jeste stres treniranja. Prema opisu Silve (Silva, 1990, prema Cox, 2005), stres treniranja je nužan nusproizvod psihofiziološkog stresa treniranja za sportsko takmičenje. Posledice stresa treniranja mogu biti pozitivne i negativne. Prema opisu Silve (1990), sagorevanje je iscrpan psihofiziološki odgovor na ponovljene neuspešne napore ispunjavanja zahteva stresa treniranja. Sagorevanje je treći stadijum sindroma stresa treniranja, prema Silvi (1990). Tri stadijuma stresa treniranja su istrošenost, pretreniranost i sagorevanje kao finalni. Nakon što kod sportiste nastupi sagorevanje, neizbežno je povlačenje iz stresnog okruženja. Radekova (Raedeke, 1997) definicija sindroma sagorevanja takođe proističe iz definicije Maslačove i Džeksona (Maslach \& Jackson, 1984). On definiše sagorevanje kao psihološki sindrom emocionalne/fizičke iscrpljenosti, smanjenog osećaja uspeha i sportske devalvacije.

Malobrojna su istraživanja sindroma sagorevanja, ali sva istraživanja objavljena su bazirana, barem delom, na perspektivi stresa (Cohn, 1990; Eades, 1990; Gould, Tuffey, Udry, \& Loehr 1996; Silva, 1990, prema Cox, 2005). Logika kojom su se vodila ova istraživanje je da je sagorevanje, a posebno njegov glavni deo emocionalna iscrpljenost, zasnovan na stresu. Postoje dva istraživanja, oba iz 1996. godine (Gould, D., Udry, E., Tuffy, S., \& Loehr, J., 1996a; Gould, D., Tuffy, S., Udry, E., \& Loehr, J. 1996b), u kojima se proučavalo izgaranje kod 30 tenisera juniora koji su doživeli ovaj sindrom i 32 tenisera juniora iz kontrolne grupe koji nisu doživeli izgaranje, sličnog uzrasta, iskustva u igri i istog pola. Teniseri sa izgaranjem, za razliku od kontrolne grupe, postigli su više rezultate na burnout upitniku, pokazali su nižu motivaciju, bili su povučeni i ređe su koristili strategije prevladavanja stresa, a razlikovali su se i na nekoliko subskala perfekcionizma (npr. veća zabrinutost zbog grešaka).

\section{Metod}

\section{Uzorak i procedura}

Uzorak je prigodan i sačinjen je od 153 profesionalna sportista, oba pola, iz najvišeg ranga takmičenja u Srbiji, pet ekipnih sportova: odbojka, fudbal, rukomet, košarka i vaterpolo. Oni su različitih godina, različitog broja sati treniranja na nedeljnom nivou i različitih godina profesionalnog sportskog staža. U istraživanju su učestvovala 92 muškarca (59.7\%) i 61 žena (39.6\%).

Starost uzorka profesionalnih sportista se kreće od 16 do 38 godina. U grupu mlađih sportista, od 16 do 22 godine, ulazi 52.3\% ukupnog uzorka, u srednju grupu, 
od 23 do 29 godina, ulazi 34\% uzorka, a u grupu starijih sportista, od 30 do 38 godina, ulazi 13.7\% ukupnog uzorka. Broj sati treniranja na nedeljnom nivou varira od $2 \mathrm{~h}$ do 30h. 50\% uzorka ulazi u grupu onih koji treniraju od $11 \mathrm{~h}$ do $18 \mathrm{~h}$ nedeljno. Od $19 \mathrm{~h}$ do $30 \mathrm{~h}$ nedeljno trenira $32 \%$ uzorka, a $18 \%$ trenira od $2 \mathrm{~h}$ do $10 \mathrm{~h}$ nedeljno. Raspon godina profesionalnog sportskog staža ide od 1 do 22 godine. $57.5 \%$ uzorka se bavi sportom profesionalno od 1 do 6 godina, 32\% uzorka se sportom profesionalno bavi od 7 do 13 godina, a $10.5 \%$ uzorka se sportom profesionalno bavi od 14 do 22 godine.

Ispitivanje je sprovedeno tokom septembra meseca 2018. godine. Ispitivani su sportisti iz Niša, Beograda, Valjeva, Stare Pazove, Kruševca i Novog Pazara. Ispitivanje je bilo anonimno, a ispitanicima je predočeno da će se dobijeni rezultati koristiti isključivo u istraživačke svrhe.

\section{Instrumenti}

Upitnik HEXACO-PI-R (Lee \& Ashton, 2004; Ashton \& Lee, 2006). Korišćena je verzija sa ukupno 60 ajtema i 6 subskala (po 10 ajtema za svaku od subskala). Ovaj instrument meri šest širokih domena ličnosti i njihove subordinirajuće aspekte. U pitanju su sledeće crte: Poštenje, Emocionalnost, Ekstraverzija, Saradljivost, Savesnost, Otvorenost. Odgovori ispitanika se raspoređuju na petostepenoj skali. Za skalu Poštenje koeficijent interne konzistencije u ovom istraživanju iznosi $\alpha=.75$; skalu Emocionalnost $\alpha=.77$; skalu Ekstraverzija $\alpha=.74$; skalu Saradljivost $\alpha=.76$; skalu Savesnost $=.74$ i skalu Otvorenost $\alpha=.76$.

Upitnik suočavanja sa stresnim situacijama (Coping Inventory for Stressful Situations - CISS; Endler \& Parker, 1990). Korišćena je adaptacija upitnika koju potpisuju Sorić i Proroković (Sorić i Proroković, 2002), a koji meri interindividualni pristup kojim se teži razviti mera stilova suočavanja. Upitnik sadrži 48 tvrdnji koje su grupisane u tri subskale (po 16 tvrdnji): Suočavanje usmereno na emocije, Suočavanje usmereno na problem i Izbegavanje. Ispitanici na petostepenoj skali izražavaju svoje odgovore u zavisnosti od stilova aktivnosti koje koriste pri susretu sa stresnom, teškom i uznemiravajućom situacijom. Koeficijent interne konzistencije za subskalu Suočavanje usmereno na emocije iznosi $\alpha=.80$, za Suočavanje usmereno na problem $\alpha=.79$, a za Izbegavanje $\alpha=.77$.

Upitnik sindroma sagorevanja kod sportista (Athlete Burnout Questionnaire - ABQ; Raedeke \& Smith, 2001). Ovaj upitnik sadrži tri subskale: Emocionalna i fizička iscrpljenost, Smanjen osećaj uspeha i Sportska devalvacija. Skala se sastoji od 15 tvrdnji, koje su prvobitno validirane na uzorku plivača, a kasnije pokazane kao primenjive i na ostalim sportistima, a svaka od subskala se sastoji od 5 tvrdnji. Odgovori ispitanika su raspoređeni na petostepenoj skali, od skoro nikad do skoro uvek. Generalnim sindromom sagorevanja je nazvana skala koja je korišćena u ovom istraživanju, a koja se odnosi na sve tri subskale zajedno. Koeficijent interne konzistencije za subskale Emocionalna i fizička iscrpljenost iznosi $\alpha=.87$. Za subskalu Smanjen osećaj uspeha $\alpha=.88$, a za subskalu Sportska devalvacija takođe $\alpha=.88$. 


\section{Rezultati}

\section{Povezanost osnovnih varijabli istraživanja}

Tabela 1

Prikaz Pirsonovih koeficijenata osnovnih varijabli istraživanja

\begin{tabular}{lccc}
\hline & $\begin{array}{c}\text { Smanjen osećaj } \\
\text { uspeha }\end{array}$ & $\begin{array}{c}\text { Emocionalna } \\
\text { i fizička } \\
\text { iscrpljenost }\end{array}$ & Sportska devalvacija \\
\hline Poštenje & -.058 & -.154 & $-.172^{*}$ \\
Emocionalnost & -.065 & -.014 & -.041 \\
Ekstraverzija & $-.223^{* *}$ & $-.272^{* *}$ & $-.327^{* *}$ \\
Otvorenost & -.021 & -.075 & .041 \\
Savesnost & -.131 & $-.321^{* *}$ & $-.217^{* *}$ \\
Saradljivost & -.066 & $-.202^{*}$ & $-.211^{* *}$ \\
Usmerenost na zadatak & $-.172^{*}$ & $-.281^{* *}$ & $-.262^{* *}$ \\
Usmerenost na emocije & -.113 & .084 & .076 \\
Izbegavanje & $-.238^{* *}$ & $-.257^{* *}$ & $-.221^{* *}$ \\
\hline
\end{tabular}

$* * p<.01 ; * p<.05$

Osobina ličnosti Poštenje je u niskoj negativnoj korelaciji sa subskalom Sportska devalvacija. Emocionalnost, kao osobina ličnosti nije u statistički značajnoj korelaciji ni sa jednom od subskala ABQ skale. Ekstraverzija je u negativnoj korelaciji sa svim subskalama, i to sa subskalama Smanjeni osećaj za uspeh i Emocionalna i fizička iscrpljenost u niskoj, a sa subskalom Sportska devalvacija u umerenoj negativnoj korelaciji. Osobina ličnosti Otvorenost nije u statistički značajnoj korelaciji ni sa jednom subskalom ABQ. Savesnost korelira negativno umereno sa Emocionalnom i fizičkom iscrpljenošću, a negativno nisko sa Sportskom devalvacijom. Saradljivost, kao poslednja osobina HEXACO inventara ličnosti, je u negativnoj niskoj korelaciji sa Emocionalnom i fizičkom iscrpljenošću i Sportskom devalvacijom. Strategija prevladavanja Usmerenost na zadatak korelira sa svim subaskalama. Korelacija je negativna i niska u sva tri slučaja. Usmerenost na emocije je u niskoj negativnoj korelaciji samo sa Smanjenim osećajem za uspeh. Izbegavanje, kao strategija prevladavanja stresa, je u niskoj negativnoj korelaciji sa sve tri subskale ABQ.

Tabela 2

Prikaz Pirsonovih koeficijenata korelacije nezavisnih varijabli istraživanja

\begin{tabular}{lccc}
\hline & Usmerenost na zadatak & Usmerenost na emocije & Izbegavanje \\
\hline Poštenje & .080 & $.164^{*}$ & -.099 \\
Emocionalnost & -.066 & .145 & $.273^{* *}$ \\
Ekstraverzija & $.249^{* *}$ & .099 & $-.229^{* *}$ \\
Otvorenost & .084 & .117 & .085 \\
Savesnost & $.349^{* *}$ & .053 & $-.318^{* *}$ \\
Saradljivost & .066 & .008 & .017 \\
\hline
\end{tabular}

$* * p<.01 ; * p<.05$ 
Subskale dve nezavisne, prediktorske varijable, osobine ličnosti i strategije prevladavanja stresa, koreliraju na sledeći način. Poštenje je u pozitivnoj, niskoj korelciji sa Usmerenošću na emocije. Emocionalnost je u pozitivnoj, niskoj korelaciji sa Izbegavanjem. Ekstraverzija pozitivno i nisko korelira sa Usmerenošću na zadatak, a sa Izbegavanjem nisko i negativno. Otvorenost ne korelira značajno ni sa jednom od subskala CISS skale. Savesnost umereno, pozitivno korelira sa Usmerenošću na zadatak i umereno, negativno sa Izbegavanjem. Saradljivost nije u statistički značajnoj korelaciji ni sa jednom od tri subskale ABQ skale.

\section{Predikcija burnout sindroma kod sportista na osnovu seta prediktorskih varijabli istraživanja}

Za ispitivanje mogućnosti predikcije burnout sindroma kod profesionalnih sporista, a na osnovu osobina ličnosti i strategija prevladavanja stresa, korišćena je hijerarhijska regresiona analiza.

Tabela 3

Osobine ličnosti i strategije prevladavanja stresa kao prediktori generalnog sindroma sagorevanja

\begin{tabular}{llcc}
\hline & Subskale & $\beta$ & $p$ \\
\hline & Poštenje & -.057 & .478 \\
& Emocionalnost & -.078 & .314 \\
Model & Ekstraverzija & -.243 & .004 \\
& Saradljivost & -.129 & .099 \\
& Savesnost & -.156 & .076 \\
& Otvorenost & .038 & .623 \\
\hline & Poštenje & -.028 & .729 \\
& Emocionalnost & -.055 & .478 \\
Dopuna modela (strategije & Ekstraverzija & -.208 & .013 \\
prevladavanja stresa) & Saradljivost & -.132 & .083 \\
& Savesnost & -.128 & .167 \\
& Otvorenost & .058 & .452 \\
& Usmerenost na zadatak & -.098 & .267 \\
& Usmerenost na emocije & .020 & .821 \\
& Izbegavanje & -.211 & .021 \\
\hline
\end{tabular}

U prvom koraku testirana je prediktivna moć osobina ličnosti (Poštenje, Emocionalnost, Ekstraverzija, Saradljivost, Savesnost i Otvorenost), čime je objašnjeno $15.7 \%$ varijanse zavisne varijable $(F(6,146)=4.527, p<.001)$. Ekstraverzija se jedina pokazala kao statistički značajan prediktor $(\beta=-.243, p=$ .004). Negativan smer regresionog koeficijenta ukazuje da su ekstravertniji sportisti manje skloni doživljaju sindroma sagorevanja.

U drugom koraku su kao prediktori uključene, pored osobina ličnosti, strategije prevladavanja stresa (Usmerenost na zadatak, Usmerenost na emocije, Izbegavanje). Time je objašnjeno dodatnih $6.3 \%$ varijanse u odnosu na prethodni model $(F(3,143)$ 
$=3.840, p=.011)$. Statistički značajan doprinos objašnjenju zavisne varijable daje subskala Izbegavanje $(\beta=-.211, p=.021)$. Negativan smer regresionog koeficijenta ukazuje da su ispitanici sa većim skorom na ovoj varijabli manje skloni da dožive sindrom sagorevanja. Od osobina ličnosti, Ekstraverzija se i u ovom modelu pokazala kao statistički značajan prediktor generalnog sindroma sagorevanja $(\beta=-.208, p=$ .013), a regresioni koeficijent je zadržao isti, negativni, smer.

Konačni model koji obuhvata osobine ličnosti i strategije prevladavanja stresa objašnjava $22 \%(F(9,143)=4.474, p<.001)$ varijanse kriterijuma.

Tabela 4

Osobine ličnosti i strategije prevladavanja stresa kao prediktori smanjenog osećaja uspeha

\begin{tabular}{llcc}
\hline & Subskale & $\beta$ & $p$ \\
\hline & Poštenje & -.003 & .975 \\
Model & Emocionalnost & -.088 & .279 \\
(osobine ličnosti) & Ekstraverzija & -.205 & .022 \\
& Saradljivost & -.023 & .781 \\
& Savesnost & -.059 & .520 \\
& Otvorenost & .012 & .881 \\
\hline & Poštenje & .018 & .831 \\
& Emocionalnost & -.038 & .644 \\
& Ekstraverzija & -.200 & .025 \\
Dopuna modela (strategije & Saradljivost & -.017 & .835 \\
& Savesnost & -.089 & .366 \\
& Otvorenost & .048 & .562 \\
& Usmerenost na zadatak & -.038 & .683 \\
& Usmerenost na emocije & -.125 & .190 \\
& Izbegavanje & -.157 & .106 \\
\hline
\end{tabular}

$\mathrm{Na}$ osnovu podataka prikazanih kroz tabelu broj 4 i prvog prediktivnog modela, možemo zaključiti da se osobine ličnosti, generalno gledano, nisu pokazale statistički značajnim prediktorom $\left(R^{2}=.061, F(6,146)=1.569, p=.160\right)$. Međutim, Ekstraverzija se pokazala kao statistički značajni prediktor, $(\beta=-.205, p=.022)$, a $\mathrm{s}$ obzirom na negativan predznak regresionog koeficijenta, možemo da zaključimo da su ekstravertniji sportisti manje skloni doživljaju smanjenog osećaja uspeha.

Dopunom modela osobina ličnosti sa strategijama prevladavanja stresa, model je postao statistički značajan $(F(9,143)=2.083, p=.035)$, a Ekstaverzija se i ovde pokazala kao statistički značajan prediktor $(\beta=-.200, p=.025)$. Konačni model objašnjava $11.6 \%$ varijanse kriterijuma, a u odnosu na prethodni model, strategije prevladavanja stresa objašnjavaju dodatnih $5.5 \%$ varijanse $(F(3,143)=2.982, p=$ $.033)$. 
Tabela 5

Osobine ličnosti i strategije prevladavanja stresa kao prediktori emocionalne i fizičke iscrpljenosti

\begin{tabular}{llcc}
\hline & Subskale & $\beta$ & $p$ \\
\hline & Poštenje & -.044 & .582 \\
Model & Emocionalnost & -.043 & .579 \\
(osobine ličnosti) & Ekstraverzija & -.150 & .075 \\
& Saradljivost & -.148 & .058 \\
& Savesnost & -.236 & .008 \\
& Otvorenost & -.012 & .879 \\
\hline \multirow{5}{*}{$\begin{array}{l}\text { Dopuna modela (strategije } \\
\text { prevladavanja stresa) }\end{array}$} & Poštenje & -.011 & .886 \\
& Emocionalnost & -.033 & .676 \\
& Ekstraverzija & -.108 & .197 \\
& Saradljivost & -.157 & .041 \\
& Otvornost & -.195 & .037 \\
& Usmerent & -.001 & .994 \\
& Usmerenost na zadatak & -.084 & .341 \\
& Izbegavanje & .084 & .349 \\
\hline
\end{tabular}

U okviru podataka prikazanih kroz tabelu broj 5 vidimo da prvi prediktivni model koji čine osobine ličnosti (Poštenje, Emocionalnost, Ekstraverzija, Saradljivost, Savesnost i Otvorenost) objašnjava $15.5 \%$ varijanse kriterijuma $(F(6,146)=4.460, p$ $<.001)$. U ovom slučaju se Savesnost pokazala kao statistički značajan prediktor, pri čemu Beta koeficijent iznosi -.236 ( $p=.008)$. Negativan smer ukazuje da ispitanici sa izraženijom savesnošću jesu manje skloni stanju emocionalne i fizičke iscrpljenosti.

U drugom koraku, testirana je prediktivna moć osobina ličnosti i CISS skale, odnosno strategija prevladavanja stresa (Usmerenost na zadatak, Usmerenost na emocije, Izbegavanje), pri čemu je objašnjeno dodatnih $5.9 \%$ varijanse u odnosu na prethodni model $(F(3,143)=3.604, p=.015)$. Subskala Izbegavanje se pokazala statistički značajnom i to na nivou $.015(\beta=-.224)$. S obzirom na negativan predznak zaključujemo da su oni ispitanici koji su skloniji pribegavanju mehanizmu Izbegavanja, kao strategiji prevladavanja stresa, manje emocionalno i fizički iscrpljeni. Od osobina ličnosti, u drugom modelu se Savesnost $(\beta=-.195, p$ $=.037)$ ponovo pokazala statistički značajnim prediktorom emocionalne i fizičke iscrpljenosti, ali i Saradljivost $(\beta=-.157, p=.041)$. Negativan smer predznaka regresionog koeficijenta ukazuje da su savesniji i saradljiviji sportisti manje skloni stanju emocionalne i fizičke iscrpljenosti.

Konačni model koji obuhvata osobine ličnosti i strategije prevladavanja stresa objašnjava $21.4 \%(F(9,143)=4.334, p<.001)$ varijanse kriterijuma. 
Tabela 6

Osobine ličnosti i strategije prevladavanja stresa kao prediktori sportske devalvacije

\begin{tabular}{llcc}
\hline & Subskale & $\beta$ & $p$ \\
\hline \multirow{4}{*}{$\begin{array}{l}\text { Model } \\
\text { (osobine ličnosti) }\end{array}$} & Poštenje & -.088 & .272 \\
& Emocionalnost & -.071 & .357 \\
& Ekstraverzija & -.263 & .002 \\
& Saradljivost & -.144 & .064 \\
& Savesnost & -.100 & .251 \\
& Otvorenost & .088 & .262 \\
\hline \multirow{5}{*}{$\begin{array}{l}\text { Dopuna modela (strategije } \\
\text { prevladavanja stresa) }\end{array}$} & Poštenje & -.066 & .410 \\
& Emocionalnost & -.067 & .394 \\
& Ekstraverzija & -.224 & .008 \\
& Saradljivost & -.149 & .052 \\
& Otvorenost & -.051 & .583 \\
& Usmerenost na zadatak & .096 & .221 \\
& Usmerenost na emocije & -.119 & .183 \\
& Izbegavanje & .068 & .451 \\
& & -.162 & .079 \\
\hline
\end{tabular}

Na osnovu podataka prikazanih kroz tabelu broj 6, gde se predviđa sportska devalvacija, uz pomoć osobina ličnosti kao prvog modela (Poštenje, Emocionalnost, Ekstraverzija, Saradljivost, Savesnost i Otvorenost), možemo reći da je model statistički značajan i da objašnjava $16 \%$ varijanse kriterijuma $(F(6,146)=4.629$, $p<.001)$. Kao statistički značajan prediktor pokazala se subskala Ekstraverzije $(\beta=-.263, p=.002)$. Kako je smer predznaka regresionog koeficijenta negativan, možemo zaključiti da ekstravertniji sportisti nisu oni koji su sportski devalvirani.

Dopunom modela osobina ličnosti sa strategijama prevladavanja stresa (Usmerenost na zadatak, Usmerenost na emocije, Izbegavanje), objašnjeno je dodatnih $4.6 \%$ varijanse u odnosu na prethodni model $(F(3,143)=2.767, p=.044)$. Ekstraverzija se i u drugom modelu pokazala statistički značajanim prediktorom sportske devalvacije $(\beta=-.224, p=.008)$, a zbog negativnog predznaka regresionog koeficijenta, tumačenje je isto kao u prethodnom modelu.

Konačni model koji obuhvata osobine ličnosti i strategije prevladavanja stresa objašnjava $20.6 \%(F(9,143)=4.121, p<.000)$ varijanse kriterijuma.

\section{Diskusija}

Glavni cilj ovoga istraživanja bio je ispitati da li su osobine ličnosti i strategije prevladavanja stresa značajni prediktori za doživljaj sindroma sagorevanja kod sportista.

Podaci dobijeni hijerarhijskom regresionom analizom pokazuju da se više faktora izdvojilo kao značajni prediktori doživljaja sindroma sagorevanja kod sportista. Od osobina ličnosti, Ekstraverzija se pokazala kao statistički značajan prediktor Smanjenog 
osećaja uspeha i Sportske devalvacije, ali i Generalnog sindroma sagorevanja, Ekstravertni sportisti su manje skloni doživljaju sindroma sagorevanja i manje su skloni da osećaju smanjen osećaj svog uspeha u sportu ili da se osećaju sportski devalvirano, odnosno, manje su skloni da razvijaju negativne emocije prema sportu kojim se bave. Kao što je već spomenuto, Morgan i (1980) i Kane (1976) su zaključili da su sportisti u osnovi ekstravertni. S obzirom na to da su ekstraverti predisponirani da osećaju pozitivne emocije (Costa \& McCrae, 1992), a kako se bavljenje profesionalnim sportom smatra poslom, pozitivne emocije su sklone da se generalizuju i na zadovoljstvo poslom, kako je demonstrirano metaanalizom uzroka zadovoljstva poslom (Connolly \& Viswesvaran, 2000). Iz ovoga se može doći do zaključka da oni koji su zadovoljniji svojim uspehom u sportu kojim se bave i generalnim statusom koji imaju u klubu za koji treniraju, manje su skloni mogućnosti da dožive sindrom sagorevanja. Takođe, dokazi upućuju i na to da ekstraverti imaju više prijatelja i provode više vremena u socijalnom okruženju i samim tim su skloniji socijalnoj facilitaciji i interakcijima sa više ljudi, koje su nagrađujuće (Watson \& Clark, 1997). U studiji ispitivanja sindroma sagorevanja kod tenisera juniora (Gould et al., 1996a), došlo se do rezultata da su oni koji nisu imali razvijen socijalni život bili skloniji da dožive sindrom sagorevanja. Kako su se u istraživanju ispitivali isključivo sportisti iz ekipnih sportova, u duhu prethodnog tumačenja o razvijenim socijalnim odnosima, možemo zaključiti da ekstraverti imaju bolje odnose sa svojim saigračima, a samim tim imaju i ugodnije trenažne (radne) sate.

Savesnost se pokazala kao statistički značajni prediktor Emocionalne i fizičke iscrpljenosti i oni ispitanici koji imaju visok skor na Savesnosti su manje skloni da dožive sindrom sagorevanja. Za sportiste, srž profesije kojom se bave je njihov performans u sportu (Raedeke, 1997). Osobe koje postižu visoke skorove na Savesnosti su zadovoljnije poslom, a kako je zaključeno da se profesionalni sport smatra poslom, konekcija je jasna. Slični rezultati dobijeni su i u prethodnim istraživanjima (Judge, Heller, \& Mount, 2002; McCrae \& Costa, 1990). Sportisti mogu biti iscrpljeni emocionalnim i fizičkim zahtevima koje sport nameće, međutim, oni koji su zadovoljni svojim performansom, manje su iscrpljeni, emocionalno, ali i fizički. Osobe sa izraženom savesnošću su odane dužnosti, ambiciozne i vredne, istrajne u ostvarivanju ciljeva i odgovorne (McCrae \& Costa, 1990), pa ne iznenađuje da pružanjem mogućnosti da sve to i ostvare raste i zadovoljstvo poslom (performansom). Savesnost je u pozitivnoj korelaciji sa istrajnošću i ličnim razvojem (Zotović, 2004). Savesne osobe ozbiljnije pristupaju poslu, ulažu veće napore $\mathrm{u}$ ispunjenju radnih zadataka $\mathrm{i}$ trude se da daju svoj maksimum u dolaženju do rešenja problema, pa samim tim kada to postignu izražavaju i veće zadovoljstvo samom prirodom posla i mogućnošću da iskažu svoje potencijale. Maslačova kaže da sportisti koji sagorevaju prestaju da brinu o sportu i kvalitetu svog performansa (Maslach \& Jackson, 1984, prema Raedeke, 1997). S obzirom na to da sportisti treniraju da bi se takmičili i da bi na tim takmičenjima (utakmicama, mečevima) ostvarivali što bolje rezultate i pobeđivali, jasno je da će oni koji su savesniji više davati svoj maksimum na treninzima i na samoj utakmici. To će usloviti bolje igračke rezultate, a zauzvrat će oni biti zadovoljniji sobom i svojim učinkom. Zbog te povratne veze između pružanja maksimuma i dobijanja pozitivnih rezultata, savesni sportisti su manje skloni da budu emocionalno i fizički iscrpljeni. 
Uključivanjem druge prediktorske varijable u model - Strategije prevladavanja stresa, varijabla Izbegavanje se pokazala statistički značajnom kod predikcije Generalnog sindroma sagorevanja i Emocionalne i fizičke iscrpljenosti. Tačnije, oni koji imaju visok skor na Izbegavanju, manje su skloni doživljaju sindroma sagorevanja. Ono što iz dosadašnjih istraživanja, o strategijama prevladavanja stresa kod sportista znamo jeste da, kada je reč o akutnom stresu u sportu, najčešće se koriste izbegavajuće strategije (Nicholls, Holt, Polman, \& Bloomfield, 2006). Iako je većina prošlih istraživanja sindroma sagorevanja gledala ovaj doživljaj iz perspektive stresa (Cohn, 1990; Silva, 1990; Smith, 1986), ne sagoreva svaki sportista koji iskusi stres (Raedeke, 1997). Izbegavanje, kao učestaliji izbor strategije prevladavanja stresa, može se objasniti i iz perspektive ekipnog sporta. Ovi sportisti su više usmereni na grupu, njenu dinamiku i grupno funkcionisanje, te u njima traže odgovor na stresnu situaciju. Sportisti iz ekipnih sportova se mogu usmeriti prema nekim zajedničkim ciljevima i zadacima, koji će ih odvratiti od stresa koji su doživeli individualno. Takođe, oni mogu od grupe tražiti dodatne informacije o stresorima i stresnoj situaciji. Kroz druženje sa članovima tima i dobijenu socijalnu podršku, oni mogu pokušati da izbegnu suočavanje sa problemom (Parker \& Endler, 1992). Sa ovim je povezana i činjenica da individualni sportisti u većoj meri doživljavaju sindrom sagorevanja od sportista koji se bave ekipnim sportom, a to se objašnjava time što individualni sportisti ulažu više truda i vremena u treninge (Coakley, 1992; Smith, 1986). Kako konkretnih rezultata, u prethodno vršenim istraživanjima, koji potvrđuju da su sportisti koji koriste Izbegavanje kao strategiju prevladavanja stresa manje skloni da dožive sindrom sagorevanja - nema, tumačenje rezultata ovog istraživanja povezujem sa prethodno iznetim činjenicama. U istraživanjima je takođe potvrđeno da za Izbegavanjem, kao strategijom prevladavanja stresa, češće posežu ženski sportisti (Sagar, Lavellee, \& Spray, 2009), pa bi bilo interesantno u narednom istraživanju ispitati povezanost između pola i ove strategije prevladavanja stresa.

Još jedna se varijabla pokazala statistički značajnim prediktorom Emocionalne i fizičke iscrpljenosti, kada su modelu priključene Strategije prevladavanja stresa, a to je dimenzija Saradljivosti. Oni sportisti koji imaju visok skor na varijabli Saradljivosti manje su skloni osećaju emocionalne i fizičke iscrpljenosti. Visok skor na dimenziji Saradljivosti se, prema Eštonu i Liju i njihovom HEXACO šestofaktorskom modelu (Ashton i Lee, 2006), tumači blagošću u procenjivanju drugih i spremnosti na kompromis i saradnju. Sportisti koji su dobili visoke rezultate na ovoj dimenziji su verovatno upućeniji na svoje saigrače i sa njima su razvili dobre međuljudske odnose. To će svakako doprineti ugodnijim trenažnim satima, te i manjoj mogućnosti za doživljaj emocionalne i fizičke iscrpljenosti.

\section{Zaključak}

Glavni cilj ovog istraživanja bilo je ispitati da li su osobine ličnosti (Poštenje, Emocionalnost, Ekstraverzija, Savesnost, Saradljivost i Otvorenost) i strategije prevladavanja stresa (Usmerenost na zadatak, Usmerenost na emocije, Izbegavanje) statistički značajni prediktori sindroma sagorevanja kod sportista. 
$\mathrm{Na}$ osnovu prikazanih rezultata, možemo zaključiti da se od osobina ličnosti Ekstraverzija pokazala kao statistički značajan prediktor Smanjenog osećaja uspeha i Sportske devalvacije, ali i Generalnog sindroma sagorevanja, dok se Savesnost pokazala statistički značajnom za Emocionalnu i fizičku iscrpljenost. Ekstravertni i savesni sportisti imaju manju verovatnoću da dožive sindrom sagorevanja.

Kada su u model dodate strategije prevladavanja stresa, Izbegavanje se pokazalo kao statistički značajno u predikciji Generalnog sindroma sagorevanja i Emocionalne i fizičke iscrpljenosti, a oni sportisti koji koriste Izbegavanje kao strategiju prevladavanja stresnih situacija, manje su skloni razvijanju ovih doživljaja. Od osobina ličnosti, Savesnost se još jednom pokazala statistički značajnim prediktorom za Emocionalnu i fizičku iscrpljenost, ali i Saradljivost. Visok skor na obe dimenzije se tumači manjom mogućnošću za doživljaj emocionalne i fizičke iscrpljenosti.

S obzirom na to da je sagorevanje u sportu veoma retko istraživano iz perspektive ovih nezavisnih varijabli, tumačenje je bilo otežano i mnogi zaključci doneseni na osnovu rezultata ovog istraživanja bili su, u većini slučajeva, upoređivani sa rezultatima donesenim na uzorku koji se odnosi na neku drugu, nesportsku populaciju i sa prethodnim teoretskim znanjem. U najvećem broju su prisutne varijable, koje su se pokazale statistički značajnim, a čijim se posedovanjem (bilo to osobine ličnosti ili strategije prevladavanja stresa) smanjuje mogućnost doživljaja sindroma sagorevanja.

Praktičan značaj ovog istraživanja ogleda se u mogućnosti boljeg prepoznavanja faktora koji utiču na javljanje sindroma sagorevanja kod sportista. Poželjno je da se oni identifikuju na vreme i samim tim omoguće prevenciju razvijanja ovog sindroma, koji je u velikom broju slučajeva uzrok povlačenja sportista iz profesionalnog sporta.

Ograničenje ovog istraživanja je to što je uzorak bio prigodan i što su u uzorak ušli samo sportisti ekipnih sportova, pa bi se uključivanjem i individulanih sportista u istraživanje, kao i povećanjem broja ispitanika, verovatno dobili drugačiji rezultati.

\section{Reference}

Allport, G. W. (1937). Personality: A psychological interpretation. New York, NY: Henry Holt and Company.

Anshel, M. H., \& Kaissidis, A. N. (1997). Coping style and situational appraisals as predictors of coping strategies following stressful events in sport as a function of gender and skill level. British Journal of Psychology, 88(2), 263-276.

Ashton, M. C., \& Lee, K., (2006). Further assessment of the HEXACO Personality Inventory: Two new facet scales and an observer report form. Psychological Assessment, 18(2), 182-191.

Burton, D., \& Raedeke, T. D. (2008). Sport psychology for Coaches. Champaign, IL: Human Kinetics.

Cherniss, C. (1980). Staff Burnout. Job Stress in the Human Services. London: Sage Publications. 
Coakley, J. (1992). Burnout among adolescent athletes: A personal failure or social problem? Sociology of sport journal, 9(3), 271-285.

Cofer, C. N., \& Johnson, W. R. (1960). Personality dynamics in relation to exercise and sport. New York, NY: Harper.

Cohn, P. J. (1990). An exploratory study on sources of stress and athlete burnout in youth golf. The Sport Psychologist, 4(2), 95-106.

Connolly, J. J., \& Viswesvaran, C. (2000). The role of affectivity in job satisfaction: A meta-analysis. Personality and individual differences, 29(2), 265-281.

Cooper, L. (1969). Athletics, activity and personality: A review of the literature. Research Quarterly. American Association for Health, Physical Education and Recreation, 40(1), 17-22.

Costa Jr, P. T., \& McCrae, R. R. (1992). Four ways five factors are basic. Personality and individual differences, 13(6), 653-665.

Costa, P. T., \& McCrae, R. R. (2008). The revised neo personality inventory (NEOPI-R). In G. J. Boyle, G. Matthews, \& D. H. Saklofske (Eds.), The SAGE handbook of personality theory and assessment. Vol. 2: Personality measurement and testing (pp. 179-198). Thousand Oaks, CA: Sage.

Cox, R. H. (2005). Sportska psihologija: Koncepti i primjene. Jasterbarsko: Naklada Slap.

Endler, N. S., \& Parker.J.D.A (1990). Multidimensional assessment of coping: A critical evaluation. Journal of personality and Social psychology, 58(5), 844-854.

Freudenberger, H. (1974). Staff Burnout. Journal of Social Issues, 30, 159-165.

Geron, E., Furst, D., \& Rotstein, P. (1986). Personality of athletes participating in various sports. International Journal of Sport Psychology, 17(2), 120-135.

Goldberg, L. (1990). An alternative "description of personality": The Big-Five factor structure. Journal of personality and social psychology, 59(6), 1216-1229.

Gould, D., Tuffy, S., Udry, E., \& Loehr, J. (1996b). Burnout in competitive junior tennis players: II. Qualitative analysis. The sport psychologist, 10(4), 341-366.

Gould, D., Udry, E., Tuffy, S., \& Loehr, J. (1996a). Burnout in competitive junior tennis players: I. A quantitative psychological assessment. The sport psychologist, 10(4), $322-340$.

Hardman, K. (1973). A dual approach to the study of personality and performance in sport. Personality and performance in physical education and sport. London: Kimpton.

John, O. P., Naumann, L. P., \& Soto, C. J. (2008). Paradigm shift to the integrative BigFive trait taxonomy: History, measurement, and conceptual issues. In O. P. John, R. W. Robins, \& L. A. Pervin (Eds.), Handbook of personality: Theory and research (3rd ed.) (pp. 114-158). New York, NY: Guilford Press.

Judge, T. A., Heller, D., \& Mount, M. K. (2002). Five-factor model of personality and job satisfaction: A meta-analysis. Journal of applied psychology, 87(3), 530-541.

Kane, J. E. (1976). Personality and performance in sport. Sports medicine.

Lee, K., \& Ashton, M. C. (2004). Psychometric properties of the HEXACO personality inventory. Multivariate behavioral research, 39(2), 329-358.

Lee, K., \& Ashton, M. C. (2008). The HEXACO personality factors in the indigenous 
personality lexicons of English and 11 other languages. Journal of Personality, 76(5), $1002-1054$.

Magni, G., Rupolo, G., Simini, G., DeLeo, D., \& Rampazzo, M. (1985). Aspects of the psychology and personality of high-altitude mountain climbers: A study on the members of the 1983 Italian Expedition to K-2 (8,611 m., Karakorum). International Journal of Sport Psychology, 16(1), 12-19.

Maslach, C., \& Jackson, S. E. (1984). Burnout in Organizational Settings. In S. Oskamp (Ed.), Applied Social Psychology Annual: Applications in Organizational Settings (Vol. 5, pp. 133-153). Beverly Hills, CA: Sage.

McCrae. R. R., \& Costa, P. T. Jr. (1990). Personality in adulthood. New York: Guilford.

Morgan, W. P. (1980). Sport personality: The credulous-skeptical argument in perspective. In W. F. Straub (Ed.), Sport psychology: An analysis of athlete behavior (pp. 330 339). Ithaca, NY: Mouvement.

Nicholls, A. R., Holt, N. L., Polman, R. C., \& Bloomfield, J. (2006). Stressors, Coping, and Coping Effectiveness Among Professional Rugby Union Players. Sport Psychologist, 20(3), 314-329.

Parker, J. D., \& Endler, N. S. (1992). Coping with coping assessment: A critical review. European Journal of Personality, 6(5), 321-344.

Paunonen, S. V., \& Ashton, M. C. (2001). Big Five factors and facets and the prediction of behavior. Journal of Personality and Social Psychology, 81(3), 524-539.

Raedeke, T. D. (1997). Is athlete burnout more than just stress? A sport commitment perspective. Journal of sport and exercise psychology, 19(4), 396-417.

Raedeke, T. D., \& Smith A. L. (2001). Development and Preliminary Validation of an Athlete Burnout Measure. Journal od Sport and Exercise Psychology, 23(4), 281-306

Reeves, C. W., Nicholls, A. R., \& McKenna, J. (2009). Stressors and coping strategies among early and middle adolescent premier league academy soccer players: Differences according to age. Journal of Applied Sport Psychology, 21(1), 31-48.

Sagar, S. S., Lavallee, D., \& Spray, C. M. (2009). Coping with the effects of fear of failure: A preliminary investigation of young elite athletes. Journal of Clinical Sport Psychology, 3(1), 73-98.

Schurr, K. T., Ashley, M. A., \& Joy, K. L. (1977). A multivariate analysis of male athlete personality characteristics: Sport type and success. Multivariate Experimental Clinical Research, 3(2): 53-68.

Silva, J. M., III. (1990). An analysis of the training stress syndrome in competitive athletics. Journal of Applied Sport Psychology, 2(1), 5-20.

Smith, R. E. (1986). Toward a cognitive-affective model of athletic burnout. Journal of sport psychology, 8(1), 36-50.

Sorić, I., Proroković, A. (2002). Upitnik suočavanja sa stresnim situacijama Endlera i Parkera. U K. Lackovic-Grgin \& Z. Penezic (Ur.), Zbirka psihologijskih mjernih instrumenata (str. 147-151). Zadar, Hrvatska: Filozofski fakultet u Zadru.

Vlajković, J. (2005). Životne krize: prevencija i prevazilaženje. Beograd: IP Žarko Albulj.

Watson, D., \& Clark, L. A. (1997). Extraversion and its positive emotional core. In R. Hogan, J. Johnson, \& S. Briggs (Eds.), Handbook of personality psychology (pp. 767-793). San Diego, CA: Academic Press. 
Zotović, M. (2004). Coping with stress: Basic conceptual and theoretical questions from the standpoint of the transactional theory. Psihologija, 37(1), 5-32.

Zotović, M. (2007). Stresna iskustva u odrastanju i afektivna vezanost adolescenata. Psihologija, 40(4), 527-542.

\author{
Neda Karaleić ${ }^{2}$ \\ University of Niš \\ Faculty of Philosophy \\ Department of Psychology \\ Niš, Serbia
}

\title{
PERSONALITY TRAITS AND COPING STRATEGIES AS PREDICTORS OF BURNOUT SYNDROME AMONG ATHLETES
}

\begin{abstract}
The paper presents the results of research whose main goal was to examine the relationship between personality traits, coping strategies and burnout syndrome, as well as to determine whether the personality characteristics and coping strategies are statistically significant predictors of burnout syndrome among sports players. The study included 153 subjects of both sexes (92 men, 61 women), athletes who play team sports (volleyball, football, handball, basketball and water polo). Instruments used in this study are various. First of all, HEXACOPI-R questionnaire for measuring six traits of personality (Lee \& Ashton, 2004; 2006). For examining coping strategies, it is used adaptation of CISS scale, authors Endler and Parker (1990), which is signed by the Sorić and Proroković (2002). Athlete burnout syndrome was measured with ABQ scale (Raedeke and Smith, 2001). The results have shown that personality trait Extraversion is statistically significant predictor of subscale reduced sense of accomplishment, sport devaluation and athlete burnout syndrome, in general. Conscientiousness is statistically significant predictor of emotional and physical exhaustion. Avoidance, one of the coping strategies, has shown as statistically significant predictor of emotional and physical exhaustion and athlete burnout syndrome in general. High scores on all the mentioned scales represent lower possibility of experiencing burnout syndrome. Prediction of athlete burnout syndrome based on a set of variables that make personality traits and coping strategies, therefore insight into the variables that are important for the athlete burnout syndrome, can certainly have significant practical implications in terms of clarification of factors which contribute experiencing athlete burnout syndrome, which happens to be one of the main psychological reasons of retreat from professional sport.
\end{abstract}

Keywords: personality traits, coping strategies, athlete burnout syndrome, athletes

Primljeno: 04. 03. 2019.

Primljena korekcija: 12. 05. 2019.

Prihvaćeno za objavljivanje: 26. 05. 2019.

${ }^{2}$ Corresponding author email: nkaraleić94@gmail.com 